\title{
Fenomena Electronic Word-of-Mouth (eWOM) Bisnis Kuliner Menggunakan Instagram oleh Food Blogger Pekanbaru
}

\author{
Thata Shafira Dwi Ananda ${ }^{1}$, Tika Mutia ${ }^{2}$ \\ ${ }^{1}$ Universitas Islam Negeri Sultan Syarif Kasim Riau \\ Email: thata.shafiraa@gmail.com
}

\begin{abstract}
The research is motivated by current technological developments, the use of social media, especially Instagram. It is known that surfing the internet makes it easy for people to access information quickly, as well as culinary information that can currently be found on Instagram. The purpose of this study is to see how Food bloggers and influencers do eWOM on Instagram so that information can spread widely quickly. This study used a qualitative descriptive method with a phenomenological approach. This research uses purposive sampling technique. Data collection is obtained through interviews, observation and documentation. The results of the research were obtained from 3 informants who found that they had a motive for doing eWOM culinary to share information, found the meaning of doing eWOM to help culinary businesses in Pekanbaru and also found communication experiences that information delivery by food blogger was not always well received by Instagram social media followers. Overall, the eWOM phenomenon has a big impact among the Pekanbaru millennial generation who use Instagram as a lifestyle.
\end{abstract}

Keywords: Phenomenon, eWOM, Instagram, food blogger, culinery

\begin{abstract}
Abstrak: Penelitian ini dilatarbelakangi oleh perkembangan teknologi saat ini, terutama penggunaan media sosial khusunya Instagram. Diketahui bahwa berselancar di internet memudahkan orang untuk mengakses informasi dengan cepat, begitu pula informasi kuliner yang saat ini bisa ditemui di Instagram. Tujuan Penelitian ini untuk mengetahui bagaimana food blogger melakukan eWOM di Instagram agar informasi tersebut dapat tersebar luas dengan cepat. Penelitian ini menggunakan metode deskriptif kualitatif dengan pendekatan fenomenologi. Penelitian ini menggunakan teknik purposive sampling. Pengumpulan data diperoleh melalui wawancara, observasi dan dokumentasi. Hasil penelitian ditemukan bahwa mereka mempunyai motif melakukan eWOM kuliner untuk berbagi informasi, melakukan eWOM untuk membantu usaha-usaha kuliner yang ada di Pekanbaru dan juga terdapat pengalaman komunikasi food blogger dimana penyampaian informasi tidak selalu diterima baik oleh followers media sosial Instagram. Secara keseluruhan fenomena eWOM ini memberi dampak yang besar dikalangan generasi milenial Pekanbaru yang menggunakan Instagram sebagai gaya hidup.
\end{abstract}

Kata kunci: Fenomena, eWOM, Instagram, food blogger, kuliner 


\section{KOMUNIKASIANA \\ Journal of Communication Studies}

Volume 3, Nomor 1, Juni 2021

P-ISSN: 2654-4695

E-ISSN: 2654-7651

\section{Pendahuluan}

Perkembangan teknologi komunikasi saat ini membawa pengaruh yang sangat besar di berbagai bidang, salah satunya yaitu pada bidang kuliner. Makanan yang merupakan kebutuhan pokok manusia kini menjadi sesuatu yang bernilai estetika dan terkadang menjadi objek foto. Kemajuan teknologi ini menjadikan manusia dituntut harus bisa menyesuaikan diri dan mengikuti perkembangan yang ada. Hal inilah yang menjadikan media sosial sebagai akses mereka mendapatkan informasi dengan cepat.

Peneliti sebagai salah satu pengguna aktif Instagram, melihat bahwa informasi mengenai kuliner di Pekanbaru sedang hype sekali dan Instagram adalah media sosial pertama kali yang masif membagikan hal-hal berbau kuliner tersebut. Dengan berkembangnya teknologi internet ini, maka akun Instagram food blogger, yaitu orang-orang yang suka kuliner lalu membagikan ke media sosial terutama Instagram melihat peluang untuk menjadikan akun Instagram-nya yang bermanfaat bagi orang lain di bidang kuliner, maka muncullah istilah eWOM (electronic word-of-Mouth)). Istilah eWOM sekarang ini dianggap sebagai evolusi dari komunikasi tradisional interpersonal yang menuju generasi baru dari cyberspace. Dalam aktivitas eWOM ini khalayak mendapatkan tingkat transparansi pasar yang tinggi, dengan kata lain khalayak memiliki peran aktif sehingga mampu mempengaruhi produk dan harga berdasarkan referensi individu (Wardiyastuti, 2017). eWOM juga dianggap mampu mendorong promosi dan membentuk corporate image yang diinginkan (Mariasih \& Setiyaningrum, 2021).

Pada dasarnya, aktivitas eWOM terjadi saat food blogger ataupun influencer melakukan hunting kuliner ataupun mendapat kiriman makanan dari para pedagang yang ingin makanannya dipromosikan. Kemudian hasil ulasan makanan tersebut diunggah pada story dan feeds Instagram untuk dilihat oleh pengikut yang kebanyakan adalah generasi milenial. Jadi generasi milenial merupakan segmentasi pasar terbesar dari akun food blogger. Sebagian besar dari mereka mengakses info-info kuliner yang direkomendasikan. Teknik yang dilakukan oleh food blogger ini adalah penyampaian mulut-kemulut yang dilakukan secara elektronik melalui Instagram. Dimensi eWOM menurut Goyette et al adalah intensitas (intensity), valence of opinion dan content (Diana \& Poernamawati, 2019).

Melihat banyaknya akun-akun kuliner ini, peneliti melihat beberapa akun Instagram kuliner yang memiliki jumlah pengikut terbanyak yaitu: @Pekanbarukuliner $(90.300$ pengikut), @pku.eatlovers_(64.000) dan @dealpku (39.400). Dari 3 akun yang disebutkan ini, masing-masing punya kekhasan tersendiri dalam membagikan ulasan kuliner terhadap pengikutnya. Penggunaan Instagram sebagai eWOM kuliner ini menjadi sebuah fenomena baru yang ada di dalam media sosial, akun-akun kuliner ini seolah menjadi pusat informasi para pengikut tentang kuliner Pekanbaru, mulai dari kuliner kekinian, kuliner daerah dan juga kuliner-kuliner khas yang sudah susah ditemui.

Instagram merupakan media sosial berbasis gambar yang memberikan layanan berbagi foto atau video secara online melalui akses internet. Instagram memiliki fitur yang beragam dan apa yang diunggah di Instagram bisa dibagikan ke media sosial lainnya. Dibandingkan dengan media sosial lain, Instagram cocok dijadikan media promosi karena tampilan visualnya. Instagram menjadi tempat menemukan berbagai macam informasi dan juga 
Instagram dapat menjadi wadah pengguna untuk mendapatkan eksistensi. Instagram merupakan media sosial yang dinilai paling efektif sebagai sarana promosi oleh pengelola industri di dunia. Seperti yang saat ini sedang booming yaitu endorse dan paid promote dari online shop kepada influencer yang memiliki banyak pengikut di Instagram (Meier et al., 2020). Interaksi yang terjadi pun dapat mempererat hubungan antara pengikut dan food blogger tersebut di dunia maya (Viviana \& Candraningrum, 2019). Penelitian lainnya pernah diteliti oleh Rosario, dkk di tahun 2019 mengenai fenomena eWOM ini. Rosario menyatakan bahwa kegiatan eWOM dapat memaksimalkan suatu bisnis kuliner karena melalui pembicaraan dari mulut ke-mulut atau dalam istilah keilmuan komunikasi merupakan salah satu bentuk komunikasi persuasif. Jika bentuk komunikasi persuasif ini dilakukan secara masif di media sosial akan menambah manfaat bagi si pelaku usaha (Babić Rosario et al., 2019). Komunikasi persuasif dapat membuat manusia menerima perubahan sosial dan kemajuan dalam teknologi sehingga dapat memenuhi kebutuhan pada kehidupan. Komunikasi-pun sesuatu yang mendasar karena apabila manusia tidak berkomunikasi artinya ia tidak bisa memahami keadaan sekitar. Contohnya mulai dari rumah tangga, tempat kerja, tempat umum maupun di mana saja manusia berada (Zaenuri \& Zaenuri, 2017).

Penelitian lainnya mengenai eWOM pernah dilakukan oleh Gultom dan Irwansyah (2021) mengenai kekuatan Instagram dengan eWOM dan influencer dalam pendekatan komunikasi pemasaran. Gaya hidup di era digital memungkinkan orang terutama para influencer untuk dapat memiliki penghasilan hanya dengan memberi sedikit komentar atau ulasan yang ternyata merupakan aktivitas komunikasi pemasaran di media sosial khususnya Instagram (Gultom \& Irwansyah, 2021).

Adapun ruang lingkup kajian yang diteliti pada penelitian ini membahas tentang Fenomena eWOM (electronic word-of-mouth) kuliner oleh Food Blogger Pekanbaru. Fenomenologi adalah salah satu tradisi dalam mendefinisikan setiap peristiwa komunikasi yang terjadi disekitar kita. Alfred Schutz merupakan tokoh perdana yang mencoba menjelaskan bagaimana fenomenologi dapat diterapkan untuk mengembangkan wawasan ke dalam dunia sosial. Kemudian Kuswarno (2009) memunculkan suatu istilah bagi fenomenologi komunikasi sebagai komunikologi. Dalam perspektif ini dapat dilihat indikator fenomena komunikasi menurut Kuswarno yakni, bagaimana motif, makna dan pengalaman komunikasi (Kuswarno, 2009). Sehingga tujuan dari penelitian adalah untuk mengetahui bagaimana food blogger melakukan eWOM mengenai kuliner, dari sisi motif, makna, dan pengalaman komunikasinya di Instagram.

\section{Metode}

Penelitian ini menggunakan paradigma interpretif dengan metode kualitatif dan pendekatan fenomenologi. Pendekatan fenemenologi mencari pemahaman mendalam, serta berusaha memahami arti peristiwa dan kaitan-kaitannya terhadap orang-orang yang berada dalam situasi-situasi tertentu. Sehingga, penelitian melalui pendekatan fenemenologi ini adalah untuk menjelaskan sesuatu pengalaman beserta makna pengalaman dalam suatu peristiwa. Schutz dalam Kuswarno memaparkan bahwa ada tiga indikator dalam penelitian fenomenologi, yakni bagaimana motif, makna, dan pengalaman komunikasi (Kuswarno, 2007). 
Subjek penelitian ini adalah para food blogger yang melakukan eWOM mengenai kuliner di Instagram, sedangkan objek penelitian adalah fenomena eWOM itu sendiri. Data primer dalam penelitian ini diambil dari wawancara dengan 3 orang food blogger Pekanbaru. Food blogger diambil dari akun kuliner dengan jumlah followers tertinggi yakni, MinFi, MinMon dan BangMin. Kemudian Data sekunder adalah data-data yang didapat interaksi antara pengikut dan yang mempunyai akun kuliner di Instagram tersebut. Data sekunder juga dapat berupa komentar, story, ataupun repost foto/ video. Peneliti menggunakan data sekunder ini untuk memperkuat penemuan dan melengkapi informasi yang telah dikumpulkan melalui wawancara langsung.

Pengalaman dari individu dalam hal ini adalah para food blogger di media sosial Instagram. Fenomena ini menjadi hal yang sangat diminati oleh pencinta kuliner yang ingin mencari referensi di Instagram. Penelitian diawali dengan menganalisis fenomena eWOM kuliner yang terjadi dikalangan generasi milenial Pekanbaru di Instagram. Sehingga peneliti membuat ilustrasi sebagai berikut: Setelah data terkumpul, dilaksanakan pengolahan data dengan metode kualitatif, setelah itu dianalisis secara kualitatif dilakukan dengan langkahlangkah sebagai mana dikemukakan oleh Moelong berikut: pertama, klasifikasi data, yakni mengkelompokkan data sesuai dengan topik pembahasan. Kedua, reduksi data, yaitu memeriksa kelengkapan data untuk mencari kembali data yang masih kurang dan mengenyampingkan data yang kurang relevan. Ketiga, deskripsi data, yaitu menguraikan data secara sistematis sesuai dengan topik pembahasan dan keempat, menarik kesimpulan, yaitu merangkum uraian-uraian penjelasan kedalam susunan yang singkat dan padat (Moelong, 2001). Pengolahan data melalui analisis deskriptif kualitatif, yaitu data yang dikumpulkan berupa kata-kata, gambar dan bukan angka-angka serta dijelaskan dengan kalimat sehingga data yang diperoleh dapat dipahami maksud dan maknanya.

Selanjutnya metode pengumpulan data dengan cara melakukan kunjungan dan pengamatan secara langsung guna untuk melihat perubahan fenomena sosial yang berkembang. Berdasarkan pelaksanaaan, observasi dapat dibagi dalam dua jenis, yaitu partisipasi dan observasi non-partisipasi. Peneliti menggunakan observasi non partisipasi, hal ini karena peneliti tidak terlibat secara langsung kedalam bagian yang diteliti, tetapi diluar dari bagian yang diteliti yang sesuai dengan permasalahan yang diambil dan diteliti.

Teknik wawancara yang digunakan dalam penelitian ini adalah wawancara mendalam (in-depth interview), yaitu teknik mengumpulkan data atau informasi dengan cara tatap muka langsung dengan informan agar mendapatkan data lengkap dan mendalam, pada wawancara mendalam ini, pewawancara relatif tidak mempunyai kontrol atau respon informan, artinya informan bebas memberikan jawaban-jawaban yang lengkap, mendalam, dan bila perlu tidak ada yang disembunyikan. Dokumentasi dilakukan untuk mendapatkan data yang di perlukan untuk melengkapi data-data penelitian, Adapun pengambilan data di lakukan pada generasi milenial Pekanbaru yang merupakan pengikut akun Instagram kuliner tersebut.

\section{Hasil dan Pembahasan}

Hasil penelitian terfokus kepada fenomena eWOM oleh food blogger di media sosial Instagram, dan berikut ini adalah tampilan profil Instagram para informan penelitian. Akun Instagram yang diteliti adalah yang jumlah followers-nya tertinggi. Ada 3 yang terkenal dengan food bloggernya yakni, @pku.eatlovers_dengan jumlah followers 64.000 di 
Instagram. Food bloggernya dipanggil dengan nama Min Fi. Ciri khas dari akun ini yaitu seperti toko berjalan, karena pemilik akun ini selalu menggunggah makanan kemasan seperti snack atau minuman yang baru rilis dipasaran kemudian diunggah di akun Instagramnya agar menarik perhatian followers.

Gambar 1. Tampilan Instagram @pku.eatlovers

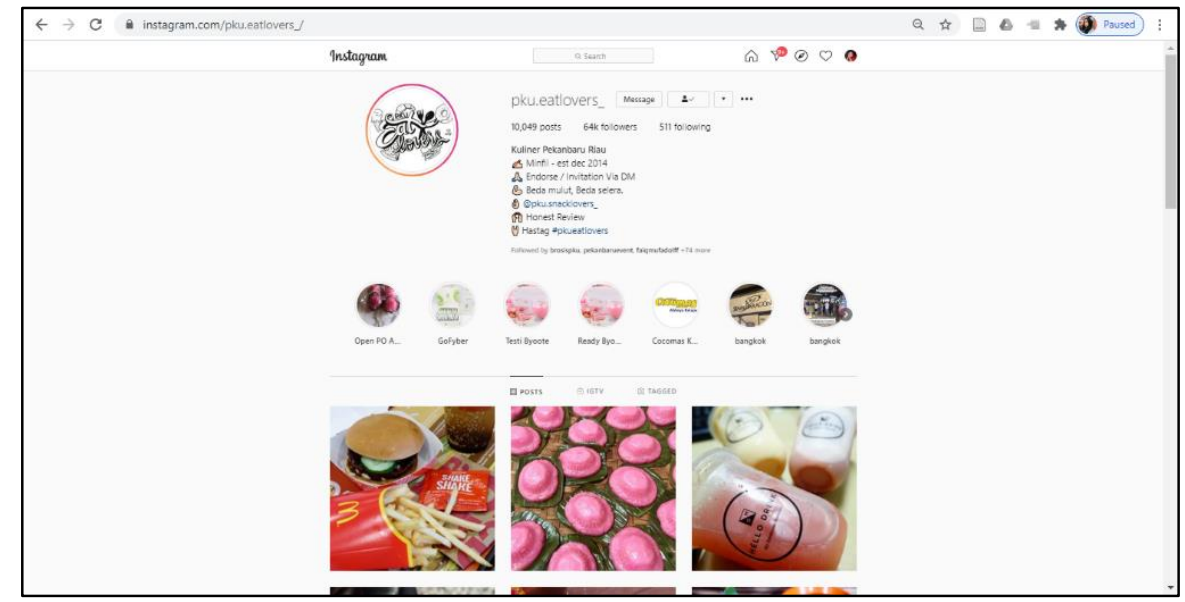

Sumber: Akun Instagram @ pku.eatlovers di https://www.Instagram.com

Akun Instagram kedua yaitu @ dealpku dengan Food blogger dipanggil dengan nama Min Mon, seorang Ibu rumah tangga (IRT). Akun ini jumlah followers-nya sebanyak 39.400 di Instagram. Ciri khas dari akun ini yaitu pemilik akun selalu membuat instastory dengan filter yang menarik agar penyampaian eWOM terlihat lebih menyenangkan.

Gambar 2. Tampilan Instagram @ dealpku

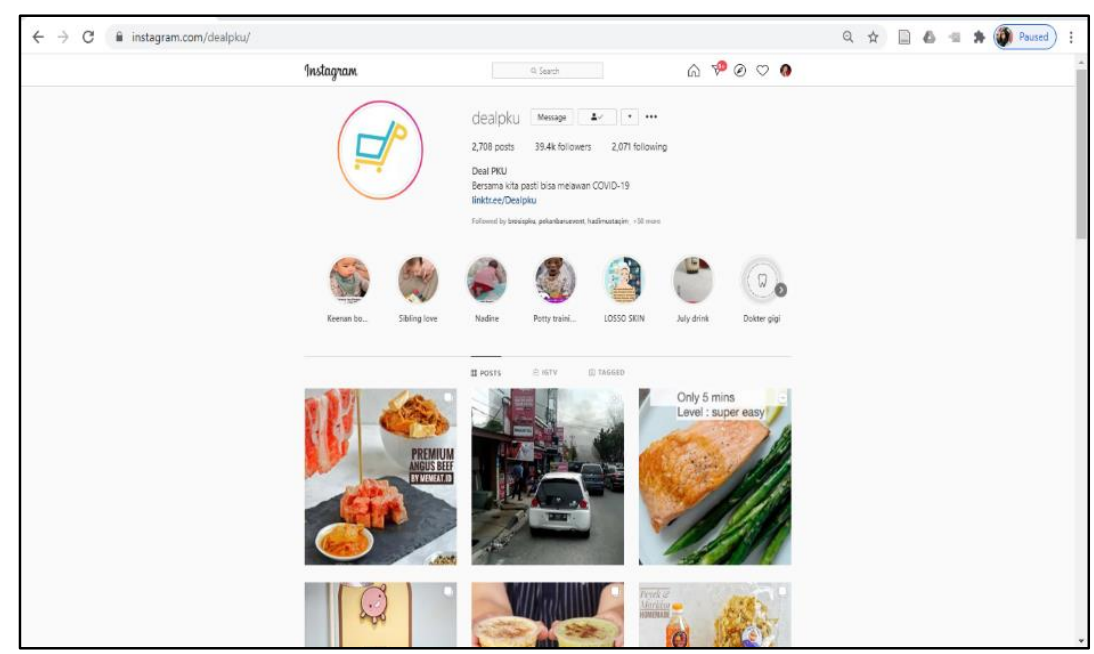

Sumber : Akun Instagram @ dealpku di https://www.Instagram.com

Terakhir, food blogger Bang Min, yaitu @Pekanbarukuliner dengan followers 90.300. Ciri khas dari akun ini adalah selalu menggunakan jargon-jargon yang mudah diingat 
oleh followers-nya, seperti "Pekanbarukuliners, juara dan look at this" dan hanya mengunggah makanan dan minuman halal.

Gambar 3. Tampilan Instagram @Pekanbarukuliner

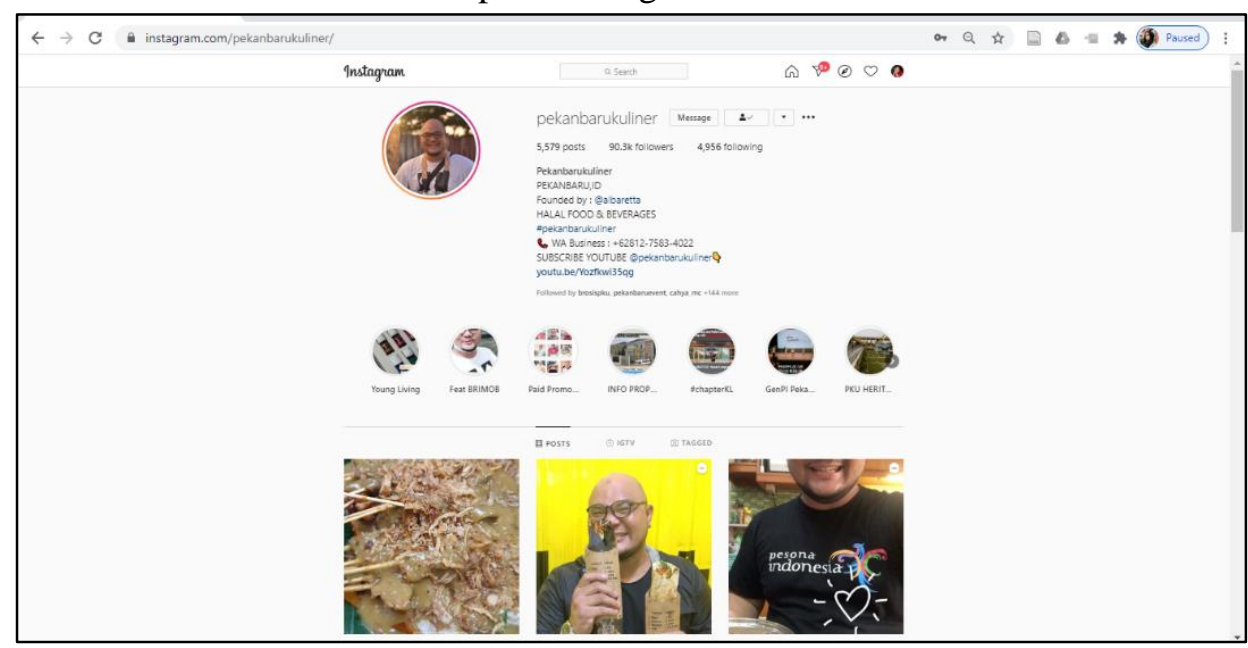

Sumber: akun Instagram @ Pekanbarukuliner di https://www.Instagram.com

\section{Motif eWOM Kuliner Food Blogger Pekanbaru di Instagram}

Motif adalah dorongan yang menggerakkan seseorang bertingkah laku dikarenakan adanya kebutuhan-kebutuhan yang ingin dipenuhi oleh manusia. Motif juga dapat dikatakan sebagai daya penggerak dari dalam dan di dalam subjek untuk melakukan aktivitas-aktivitas tertentu demi mencapai suatu tujuan. Dalam memutuskan untuk melakukan suatu hal seseorang tentu memiliki sebuah motif untuk menjalankan keputusan tersebut. Selain itu dalam referensi lainnya motif juga dapat kita kenali sebagai dorongan untuk menetapkan suatu pilihan perilaku yang secara konsisten dijalani oleh seseorang sedangkan alasan adalah keputusan yang pertama kali keluar pada diri seseorang ketika dirinya mengambil suatu tindakan tertentu (Kuswarno, 2009).

Dari observasi dan wawancara penelitian didapatkan bahwa yang menjadi motif eWOM pada informan penelitian yang merupakan food blogger di Pekanbaru dari hasil observasi adalah untuk memberikan update dan memberi informasi di media sosial seputar kuliner, karena saat sekarang ini generasi milenial selalu butuh referensi makanan sepanjang waktu. Bila kita bahas mengenai motif eWOM masing-masing informan mereka memiliki motif dan alasan yang berbeda namun, tetap memiliki satu tujuan yang sama. Adapun yang menjadi motif eWOM yang digunakan informan penelitian adalah, pertama hobi makan/ kuliner. Kuliner sekarang sudah menjadi trend bagi semua usia. Kecenderungannya sudah seperti menu setiap sebulan sekali, terkadang banyak di antara orang-orang yang rela berkunjung kesuatu tempat yang jauh dari tempat tinggalnya hanya untuk mencari sensasi yang berbeda dari makanan yang mereka makan. Para pemburu kuliner ini melihat diawal tentang makanan apa yang akan mereka makan dari beberapa sumber. Hobi kuliner ini merupakan salah satu motif yang mendasari dalam melakukan eWOM, sebagaimana hasil wawancara berikut ini: 
"Berhubung saya menyukai segala sesuatu tentang makanan, saya suka mengabadikannya dalam bentuk foto, selain itu saya juga membuat akun ini untuk membantu mempromosikan usaha-usaha kuliner yang ada di Kota Pekanbaru khusunya UMKM dan juga untuk memperkenalkan/ mempromosikan Pekanbaru ke nasional maupun internasional, tetapi dengan jalan yang saya kuasai” (wawancara dengan Bang Min @Pekanbarukuliner, 2020).

Dari sini dapat peneliti analisis bahwa di antara pelaku eWOM yang ternyata mendapatkan keuntungan secara finansial akan hobi ini. Hobi makan yang saat ini merupakan gaya hidup di kalangan generasi milenial banyak dijadikan sebagai media untuk berbagi foto dan video dan yang nantinya akan memberikan keuntungan bagi siapa saja yang membagikannya.

Kedua, mengikuti trend kuliner. Akhir-akhir ini bisnis food and beverages merupakan salah satu bisnis yang banyak digeluti oleh generasi milenial, banyak di antara mereka yang merupakan pelaku bisnis tersebut membuat menu-menu makanan baru dengan rasa yang berbeda dan bentuk yang unik sehingga menghasilkan banyak atensi di kalangan generasi milenial. Jika kita kaitkan trend kuliner ini terhadap eWOM, salah satu informan dalam penelitian ini menjadikan trend kuliner ini sebagai salah satu motif dari fenomena eWOM. MinFi@pku.eatlovers_mengatakan bahwa:

"Akun saya selalu dibilang SPV toko berjalan (karena saya selalu posting snack snack terbaru, barang terbaru, minuman kemasan kotak) dan followers saya tau kalau saya orangnya mereview segala sesuatu sesuai dengan lidah saya. Kalau dulu awal selalu dibilang kasar karena terlalu jujur dan nyakitin, mengikuti perkembangan tahun saya mulai mengubah cara mereview saya, tidak terlalu menjudge, tapi tetap jujur karena sesuai icon logo saya, beda mulut beda selera." (Wawancara dengan Min Fi, 2020).

Dari narasumber di atas dapat kita tarik kesimpulan bahwa terkadang selain trend kuliner tersebut dijadikan sebagai motif dari fenomena eWOM kuliner, trend kuliner terkadang juga dapat dijadikan sebagai salah satu ciri khas dari suatu akun media sosial. Tak ayal dengan adanya trend tersebut menjadikan banyak di antara pelaku bisnis berlombalomba menyajikan makanan yang dapat menarik perhatian banyak orang serta makanan yang belum pernah dijualnya sebagai media penarik pelanggan. Tentunya para pelaku bisnis ini juga menggunakan media sosial seperti Instagram sebagai media informasi makanan baru yang mereka sajikan.

Ketiga, menyukai food photography. Perkembangan teknologi turut menciptakan suatu tren, khususnya di media sosial. Fotografi mulai menemukan interest yang baru seperti travel photography, landscape photography, sampai food photography. Perkembangan teknologi memang kerap menciptakan suatu profesi atau lapangan kerja baru. Sebut saja youtuber, selebgram, influencer sampai buzzer. Food photographer adalah suatu profesi yang berkembang berkat media sosial. Jika diolah dan dikembangkan secara profesional, profesi ini justru mendatangkan pundi-pundi yang melebihi gaji karyawan kantoran. Dengan berkembangnya trend makanan dengan bentuk yang unik dan tidak biasa terkadang juga 
dapat dijadikan sebagai salah satu objek fotografi yang menjanjikan dan menghasilkan banyak perhatian dari kalangan generasi milenial, tak heran jika kegiatan food photography ini juga merupakan salah satu alasan dan motif dari adanya fenomena eWOM di kalangan generasi milenial kota Pekanbaru. MinFi @ pku.eatlovers_dalam wawancara mengatakan bahwa:

"Saya membangun account ini dengan tujuan second account, di mana saya ingin meng-share foto makanan yang saya ambil secara pribadi" (Wawancara dengan Min Fi, 2020).

Dari wawancara tersebut, terlihat bahwa informan yang bernama Min Fi sangat menyukai aktivitas food photography sehingga membuat akun Instagram tersendiri untuk bisa memosting koleksi foto makanan secara lebih rinci dan lengkap.

Keempat, berbagi postingan mengenai kuliner. Dengan perkembangan zaman dan teknologi yang begitu maju pada saat sekarang ini, mengakibatkan banyak di antara generasi millennial menjadikan media sosial sebagai tempat untuk berbagi pengalaman dan informasi sebagai salah satu dari kebutuhan gaya hidup. Salah satu postingan yang sering kita jumpai di media sosial yang salah satunya adalah Instagram adalah postingan mengenai Kuliner. Jika dilihat lebih lanjut terhadap akun-akun yang membagi postingan kuliner ini cukup banyak mendapatkan perhatian pengguna Instagram, hal ini terbukti dengan banyaknya akun kuliner dengan pengikut yang cukup besar bahkan terkadang setara dengan pengikut dari akun tokohtokoh publik. Untuk Kota Pekanbaru akun-akun Instagram yang membagikan postingan mengenai kuliner cukup mudah untuk kita temukan.

Kelima, sebagai media berbagi informasi kuliner. Dengan adanya media Instagram menjadikan informasi yang kita unggah dapat diakses oleh siapapun dan informasi tersebut dapat tersebarluas dengan cepat. Seperti halnya yang disampaikan oleh informan penelitian 2 yakni@dealpku (MinMon) mengatakan yang menjadi motif beliau untuk membuat akun Instagram kuliner awalnya bertujuan untuk groupon yang nantinya juga bertujuan untuk komersial, namun tidak berjalan dengan baik, dan setelah pemilik akun menjadikan akun tersebut menjadi akun berbagi informasi kuliner yang dikhususkan kepada ibu-ibu muda yang menyukai informasi kuliner dan keenam, sebagai media promosi kuliner. Banyak usaha kuliner yang ada di Kota Pekanbaru ini, merupakan usaha yang sejak lama di bangun dan juga banyak di antara usaha tersebut yang baru merintis, para pedagang tersebut pastinya harus mengenalkan produk mereka ke khalayak. Terlebih lagi saat pandemi seperti sekarang ini. Menggunakan jasa food blogger ini merupakan salah satu langkah untuk promosi di media sosial. Seperti yang dikatakan oleh Min Fi, ia menerima tawaran kerjasama promosi kuliner yang dua kali lebih besar dibanding sebelum pandemi.

Dari beberapa motif eWOM yang dilakukan oleh para food blogger tersebut dapat dianalisis sebagai bentuk gaya hidup terutama dikalangan generasi muda saat ini yang mendominasi media sosial di Indonesia. eWOM yang merupakan kata-kata yang disebarluaskan secara elektronik mengenai informasi kuliner dapat memberi manfaat kepada pelaku usaha. eWOM merupakan jalan praktis yang bisa ditempuh. Dalam penelitian Rosario, ada tiga tahapan eWOM yakni proses, bagaimana pembuatan eWOM, paparan dan evaluasi 
dari aktivitas eWOM tersebut (Babić Rosario et al., 2019). Semua komponen ini tentu tidak akan terlaksana jika para food blogger tidak memiliki motif untuk melaksanakan eWOM.

\section{Makna eWOM Kuliner di Kalangan Food Blogger Pekanbaru di Instagram}

Makna tradisional word-of-mouth (WOM) memegang peranan penting dalam aktivitas komunikasi antara komunikator dan komunikan, namun seiring dengan perkembangan internet, saat ini WOM telah berkembang menjadi electronic word-of-mouth (eWOM). Media sosial sebagai media baru saat ini telah menciptakan kesempatan kepada eWOM berkomunikasi melalui berbagai macam media seperti forum diskusi, electronic bulletin board, news group, blog, dan social networking. Saat ini salah satu media sosial yang sering digunakan oleh para food blogger ini sebagai media eWOM adalah Instagram.

Seperti yang sudah disampaikan sebelumnya, memosting kuliner di Instagram merupakan sebuah gaya hidup dan ternyata media sosial juga menjadi akses untuk membantu para pelaku usaha baru. Kebanyakan ibu rumah tangga hanya menghabiskan waktunya di rumah untuk menjaga anak dan juga kegiatan rumah tangga lainnya, tentu saja ibu-ibu tersebut dibekali smartphone sebagai hiburan untuk mengakses media sosial, khususnya media sosial Instagram.

Usaha kuliner ini tentu saja dibangun dari warga lokal yang nantinya bukan hanya di kenal di satu daerah saja tetapi bisa di kenal secara nasional dan internasional. Seperti yang sudah disampaikan sebelumnya, memosting kuliner di Instagram merupakan sebuah gaya hidup apalagi pada kalangan generasi milenial Pekanbaru, dan ternyata media sosial juga menjadi akses untuk membantu para pelaku usaha baru, sebagaimana dengan hasil wawancara dengan Minfi @pku.eatlovers_berikut:

"Awal bermula ketika akun Instagram ini beranjak ke followers 6.000 an, awal itu dimulai pada tahun 2015. kebetulan ada 1 cafe (memo cafe) di citraland yang menggundang saya untuk mereview menu-menu mereka lalu perlahan datang undangan/ endorsement saya tidak pernah memungut biaya sampai followers saya di atas 20 ribu baru saya menetapkan tarif. Tapi terkadang, jika saya melihat suatu usaha yang baru dan orang tersebut baru mulai berjualan biasa saya bantu tanpa meminta biaya. Karena account saya, termasuk pribadi dan tidak menggunakan team. Saya bisa bebas membantu siapa yg ingin saya bantu, tanpa harus memungut suara team” (Wawancara dengan Min Fi, 2020).

Jelas bahwa Minfi @pku.eatlovers_ini memaknai bahwa ia tak menyangka apa yang dilakukan berpengaruh besar dalam melakukan eWOM kuliner di kalangan generasi milenial Pekanbaru di Instagram. Dari penjelasan hasil wawancara tersebut terlihat bahwa komunikasi dua arah sangat mungkin terbentuk melalui aktivitas eWOM di media sosial Instagram. Melalui eWOM percakapan bisa terjadi dengan intensif melalui postingan, komentar atau bahkan live. Hal ini senada dengan yang disampaikan dalam peneltian Meidy (2020) bahwa keterlibatan eWOM melalui media sosial Instagram menghasilkan kredibilitas informasi di kalangan milenial (Meidy et al., 2020). 


\section{Pengalaman Komunikasi Food Blogger di Instagram}

Dalam era modern, kegiatan komunikasi saat ini telah didukung oleh media yang membantu orang-orang dalam menyampaikan informasi secaral luas. Dahulu umumnya orang-orang berkomunikasi secara langsung dengan mulut kemulut, dan komunikasi dengan cara ini menghasilkan informasi yang jelas antara komunikan dan komunikator. Hal tersebut merupakan sebuah nilai tambah dari komunikasi langsung (word-of-mouth) namun dengan komunikasi secara langsung ini menjadikan informasi tersebut tersebar secara terbatas, dengan kemajuan teknologi sekarang informasi dapat diakses oleh siapapun dan juga banyak media yang dapat mengakses informasi tersebut secara cepat salah satunya Instagram. Instagram saat ini merupakan media sosial yang paling banyak digunakan di Indonesia umumnya dan Pekanbaru khususnya telah menjadi platform utama yang diakses oleh para generasi milenial. Salah satu konten yang sering diunggah di platform Instagram adalah konten yang berisi tentang kuliner, banyak di antara konten tersebut terkadang menghasilkan keuntungan oleh beberapa pihak yang memanfaatkan sesuai kebutuhan para pengguna lain. Berhubungan dengan penelitian yang peneliti lakukan terkait dengan fenomenologi eWOM kuliner di kalangan generasi milenial Pekanbaru di Instagram masing-masing informan penelitian memiliki pengalaman komunikasi tersendiri selama menjadi pengelola akun Instagram yang menyediakan konten kuliner.

Peneliti menjabarkan dan membagi pengalaman komunikasi yang terjadi dalam eWOM kuliner di Instagram adalah pengalaman menyenangkan dan tak menyenangkan. Bentuk pengalaman komunikasi yang menyenangkan dirasakan oleh informan yaitu informan memiliki banyak teman dan relasi, informasi yang diberikan mendapat respon positif, dan juga membantu orang-orang yang ingin mempromosikan usahanya agar lebih diketahui orang banyak. Sedangkan pengalaman komunikasi tak menyenangkan berdasarkan observasi peneliti juga didapati bahwa dari ketiga informan ini berhasil melakukan eWOM namun juga disertai dengan pro dan kontra. Bentuk pengalaman komunikasi yang dirasakan oleh informan, yaitu informan memiliki banyak teman dan relasi, informasi yang diberikan mendapat respon positif, dan juga membantu orang-orang yang ingin mempromosikan usahanya agar lebih diketahui orang banyak. Seperti hasil wawancara berikut ini:

"Saya bisa banyak kenalan dengan orang orang, saya bisa membantu para pedagang kecil yg ingin menjajakan usahanya, mendapatkan tambahan jajan dan mencoba beragam kuliner" (Wawancara dengan Min Fi, 2020).

"Suka nya nambah banyak teman, terus juga kitanya banyak belajar dari orang lain” (Wawancara dengan Min Mon, 2020).

Sebagian besar feed back yang didapat adalah baik. Kemudian para informan juga berharap para pelaku kuliner dapat memanfaatkan media sosial Instagram sebagai penunjang promosi usaha mereka karena media sosial Instagram saat ini mempunyai pengaruh yang cukup besar terutama komunikasi eWOM-nya dan juga para pengguna media sosial Instagram dapat lebih bijak menggunakan media sosial, saling menghargai kepada para user yang disebut sebagai food blogger ataupun influencer ketika sedang melakukan tugasnya mengunggah konten yang dibuat dengan effort serta butuh totalitas dan profesionalitas. 
Teori Alfred Schutz mengatakan bahwa manusia adalah makhluk sosial yang akan selalu melakukan tindakan sosial. Tindakan sosial ini berorientasi pada perilaku manusia dimasa lalu, masa sekarang dan juga masa depan. Fenomenologi adalah bagaimana memahami tindakan sosial melalui penafsiran. Proses ini dapat digunakan untuk memperjelas konsep kepekaan yang implisit. Maka setiap individu bisa menggunakan simbol-simbol yang telah diwariskan padanya, untuk memberi makna pada tingkah lakunya sendiri (Kuswarno, 2009). Penelitian Fenomenologi pada hakekatnya adalah berhubungan dengan interprestasi terhadap realitas. Fenomenologi mencari jawaban tentang makna dari suatu fenomena. Seperti halnya dalam penelitian ini, bagaimana para informan memulai interaksi menggunakan eWOM kuliner di Instagram, mendapatkan makna kehidupan di media sosial ketika melakukan eWOM dan juga harapan kedepannya untuk para pelaku kuliner.

eWOM (electronic word-of-mouth) merupakan sarana komunikasi yang berupa saran negatif ataupun positif yang terjadi di internet (Babić Rosario et al., 2019). Setiap orang yang telah mengonsumsi sebuah produk akan memberikan ulasan terhadap produk tersebut dan akan menyampaikannya di media sosial yang biss diakses oleh orang lain. Internet telah menyebarkan informasi dari mulut-kemulut secara simultan di mana-mana dan menjadi keharusan secara fisik (Hennig-Thurau et al., 2004).

Motif yang menjadikan informan melakukan eWOM di antaranya yaitu dimulai dari hobi kuliner, menyukai food photography, dan juga memang berniat untuk membantu para pelaku kuliner dalam memasarkan produknya. Karena kekuatan media sosial sangat berpengaruh dalam menarik massa. Banyak pelaku kuliner seperti pedagang yang baru merintis usaha membutuhkan promosi yang cepat diketahui banyak orang, seperti yang dijelaskan sebelumnya generasi milenial ini bisa disebut sebagai peran utama, para informan merupakan orang-orang yang bisa di klaim orang lain dengan sebutan food blogger yang di mana jika mereka mengunggah konten kuliner pasti setidaknya ada beberapa persen followers yang terpengaruh. Kemudian makna, yaitu apa yang didapatkan oleh para informan setelah melakukan eWOM ini, yaitu mempengaruhi orang banyak bahwa menggunakan media sosial sebagai sarana informasi ternyata memudahkan untuk berinteraksi jarak jauh. Pengalaman komunikasi yang didapat informan di antaranya ada pengalaman menyenangkan dan pengalaman tak menyenangkan, pengalaman menyenangkan yang dialami yaitu mendapat banyak relasi dan juga banyak belajar dari orang lain selaku pelaku kuliner, kemudian pengalaman tak menyenangkan yang dialami informan ini adalah bahwa ada beberapa oknum yang rasis terhadap mereka dan juga menganggap sepele tentang pengaruh media sosial Instagram di bidang kuliner ini.

Media sosial berbasis gambar yang memberikan layanan berbagi foto atau video secara online melalui akses internet. Instagram memiliki fitur yang beragam dan juga apa yang diunggah di Instagram bisa dibagikan ke media sosial lainnya. Dibandingkan dengan media sosial lain, Instagram cocok dijadikan media promosi karena tampilan visualnya (Damayanti, 2020). Para kalangan generasi milenial ini menjadikan Instagram sebagai bentuk perantara agar eWOM tersebut dapat tersebar secara cepat dan dapat diakses oleh siapapun (Viviana \& Candraningrum, 2019). Dalam era modern ini penggunaan Instagram sudah menjadi seperti kebutuhan dan gaya hidup kalangan generasi milenial khusunya di Pekanbaru, potret kuliner yang semakin pesat dan juga konsumtif terhadap kuliner menjadikan eWOM sebagai bentuk komunikasi yang saat ini marak dilakukan. 


\section{Simpulan}

Berdasarkan temuan penelitian maka, diperoleh kesimpulan sebagai berikut; motif yang digunakan oleh para food blogger pada awal mula eWOM terjadi diawali dengan hobi memotret kuliner, menyukai makanan dan juga ingin berbagi informasi karna mengunggah foto atau video di media sosial bagi mereka saat ini sudah sebagai gaya hidup. Makna eWOM sebagai gaya hidup oleh para food blogger ditandai dengan aktivitas eWOM yang mereka lakukan sudah berjalan lebih dari 5 tahun. Pada awalnya, akun-akun yang dimiliki para informan hanya untuk mengunggah konten makanan dan lambat laun menjadi akun food blogger, meskipun istilah ini datang dari followers mereka sendiri. Selain itu, terbentuk pengalaman komunikasi para food blogger dalam menjalankan akun Instagram yang menyajikan konten kuliner berkaitan dengan eWOM pada food blogger di kota Pekanbaru. Ada beberapa pengalaman menyenangkan dan tidak menyenangkan. Adapun pengalaman komunikasi menyenangkan yang didapat yaitu para food blogger memiliki banyak teman dan relasi, informasi yang diberikan mendapat respon positif, dan juga membantu orang-orang yang ingin mempromosikan usahanya agar lebih diketahui orang banyak. Sedangkan pengalaman komunikasi tidak menyenangkan dalam aktivitas eWOM food blogger adalah terkadang bertemu dengan toxic people dan komentar rasis yang diposting pada konten eWOM di Instagram. Secara keseluruhan, eWOM kuliner di Instagram ini memberikan fenomena tersendiri kalangan generasi milenial dan juga para pelaku kuliner untuk menginformasikan kuliner, mempromosikan usaha-usaha kuliner secara lebih up to date sehingga dapat memajukan usaha kuliner agar lebih diketahui banyak orang dengan gaya yang lebih kontemporer di era digital saat ini.

\section{Referensi}

Kementrian Pemberdayaan Perempuan dan Perlindungan Anak, (2008). Statistik Gender Tematik: Profil Generasi Milenial Indonesia,

Babić Rosario, A., de Valck, K., \& Sotgiu, F. (2019). Conceptualizing the electronic word-ofmouth process: What we know and need to know about eWOM creation, exposure, and evaluation. Journal of the Academy of Marketing Science 2019 48:3, 48(3), 422-448. https://doi.org/10.1007/S11747-019-00706-1

Damayanti, A. (2020). Instagram as a Medium of Risk Communication in COVID-19 Pandemic: A Netnography Study of Virtual Community KawalCOVID19.id). Jurnal Komunikasi Pembangunan, 18(02), 176-193. https://doi.org/10.46937/18202032355

Diana, O. :, \& Poernamawati, E. (2019). ANALISIS DIMENSI ELECTRONIC WORD OF MOUTH (EWOM) DAN PENGARUHNYA TERHADAP MINAT KUNJUNGAN PADA OBYEK WISATA DI MALANG RAYA. Adbis: Jurnal Administrasi Dan Bisnis, 12(2), 127-137. https://doi.org/10.33795/J-ADBIS.V12I2.50

Gultom, A. P. A., \& Irwansyah, I. (2021). Kekuatan Instagram dengan Electronic-Word-ofMouth (Ewom) dan Influencer dalam Komunikasi Pemasaran. Jurnal InterAct, 10(2), 35-46. https://doi.org/10.25170/INTERACT.V10I2.3150

Hennig-Thurau, T., Gwinner, K. P., Walsh, G., \& Gremler, D. D. (2004). Electronic word-ofmouth via consumer-opinion platforms: What motivates consumers to articulate themselves on the Internet? Journal of Interactive Marketing, 18(1), 38-52. https://doi.org/10.1002/DIR.10073 
Kuswarno, E. (2009). Fenomenologi: metode penelitian komunikasi : konsepsi, pedoman, dan contoh penelitiannya. In Seri metode penelitian komunikasi. Widya Padjadjaran. https://books.google.co.id/books?id=MBsnQwAACAAJ

Mariasih, A. A., \& Setiyaningrum, A. (2021). Peran eWOM Quality, eWOM Quantity, dan eWOM Credibility dalam Membentuk Corporate Image dan Mendorong Purchase Intention: Studi Empiris pada Jasa Pendidikan. JURNAL MANAJEMEN DAN BISNIS SRIWIJAYA, 19(1), 1-20. https://doi.org/10.29259/JMBS.V19I1.13007

Meidy, R. F., Suhartanto, D., \& Senalasari, W. (2020). Keterlibatan Pemasaran Elektronik Mulut ke Mulut Melalui Media Sosial Instagram: Bukti Empiris dari E-commerce Hijup. Prosiding Industrial Research Workshop and National Seminar, 11(1), 1060-1065. https://doi.org/10.35313/IRWNS.V11I1.2164

Meier, A., Gilbert, A., Börner, S., \& Possler, D. (2020). Instagram Inspiration: How Upward Comparison on Social Network Sites Can Contribute to Well-Being. Journal of Communication, 70(5), 721-743. https://doi.org/10.1093/JOC/JQAA025

Viviana, C., \& Candraningrum, D. A. (2019). EWOM Oleh Kalangan Milenial Terhadap Akun @makansampaikenyang Sebagai Pemberi Rekomendasi Kuliner. Prologia, 2(2), 270-277. https://doi.org/10.24912/PR.V2I2.3587

Zaenuri, A., \& Zaenuri, A. (2017). Teknik Komunikasi Persuasif dalam Pengajaran. JALIE; Journal of Applied Linguistics and Islamic Education, 1(1), 41-67. https://doi.org/10.33754/jalie.v1i1.83

Wardiyastuti, Devita. (2017). "Pengaruh Electronic Word of Mouth terhadap minat beli konsumen melalui brand image (studi pada followers Instagram wedangan radjiman sebagai calon konsumen).

Watt and Berg, (1995). Research Methods for Communication Science. (Boston; Allyn and Bacon).

Xia \&Bechawati, (2011). Word of mouse: The role of cognitive personalization in online consumer reviews. 